\title{
Carbohydrate-Derived Organocatalysts for the Reduction of Imines with Trichlorosilane
}

\author{
Xin Ge' ${ }^{1}$ Chao Qian ${ }^{2 *}$, Xinzhi Chen ${ }^{2}$ \\ ${ }^{1}$ School of Chemical and Material Engineering, Jiangnan University, Wuxi, China \\ ${ }^{2}$ Key Laboratory of Biomass Chemical Engineering of Ministry of Education, College of Chemical and Biological \\ Engineering, Zhejiang University, Hangzhou, China \\ Email: "qianchao@zju.edu.cn
}

Received April 2015

\section{Abstract}

The backbone of D-glucosamine hydrochloride was fine-tuned and modified by protecting the hydroxyl groups. In order to reduce imines with trichlorosilane, the carbohydrate-derived organocatalysts were prepared and screened. Methyl-4,6-0-benzylidene-2-amino-2-deoxy- $\alpha$-D-glucopyr anoside was found as the best catalyst. The reduction was proceeded under $\mathrm{CHCl}_{3}$ as solvent at $40^{\circ} \mathrm{C}$, affording $68 \%$ - $94 \%$ yield.

\section{Keywords}

\section{Carbohydrate, Organocatalyst, Reduction, Imine}

\section{Introduction}

The reduction of imines is an attractive approach for preparing amines, which have a wide application in the pharmaceuticals, agricultural chemicals and bioactive compounds [1]. In addition to the reductive amination catalyzed by the transition metals [2], boranes [3] and borohydrides [4], an organocatalytic approach is a promising method to obtain amine compounds [1]. In the organocatalytic approach, trichlorosilane and Hantzsch dihydropyridine were separately used as reducing agents for the reduction of imines in the presence of organocatalyst. Moreover, organocatalysis has received hot attention to catalyze the reaction. In spite of the rapid development of organocatalysts, it is important to continue exploiting and developing more organocatalysts.

Until now, carbohydrates have been developed as organocatalysts for application in organic synthesis [5]. In 2007, Becker et al. [6] reported enantioselective Streck and Mannich reactions catalyzed by D glucosa-minederived bifunctional urea schiff base organocatalysts. Subsequently, Becker et al. [7] synthesized carbohydratederived bifunctional primary amine-thiourea catalysts to catalyze Michael addition of aromatic ketones with nitroolefins. In 2003, Dekamin et al. [8] used the chitosan as recoverable and reused catalyst for the expeditious synthesis of $\alpha$-amino nitriles and imines under mild conditions. In our preliminary work, we developed the carbohydrate-derived amino alcohols [9] and novel carbohydrate-derived prolinamide [10] to catalyze asymmeteric

\footnotetext{
*Corresponding author.
}

How to cite this paper: Ge, X., Qian, C. and Chen, X.Z. (2015) Carbohydrate-Derived Organocatalysts for the Reduction of Imines with Trichlorosilane. Journal of Materials Science and Chemical Engineering, 3, 48-53. 
aldol reaction. As a part of our continued interests in carbohydrates [9]-[16], herein we reported carbohydratederived organocatalysts for the reduction of imines with trichlorosilane.

\section{Experimental Details}

\subsection{General Methods}

Melting points were determined on an X4-Data microscopic melting point apparatus and were uncorrected. Optical rotation values were measured on a PerkinElmer P241 polarimeter operating at $589 \mathrm{~nm}$. Nuclear magnetic resonance (NMR) spectra were measured at $400 \mathrm{MHz}\left({ }^{1} \mathrm{H}\right)$ or at $100 \mathrm{MHz}\left({ }^{13} \mathrm{C}\right)$ on a Bruker Avance DRX400 spectrometer. All reactions were monitored by analytical thin-layer chromatography (TLC) from Merck with detection by spraying with $5 \%(\mathrm{w} / \mathrm{v})$ phosphomolybdic acid in ethanol and subsequent heating or UV. All reagents and solvents were general reagent grade unless otherwise stated.

\subsection{The Synthesis of Carbohydrate Derived Organocatalysts 4-5}

The carbohydrate derived organocatalysts $\mathbf{4 - 5}$ were prepared by previously described methods. [9] [10] [17] [18]

\subsection{Methyl-4,6-0-Benzylidene-2-Amino-2-Deoxy- $\alpha$-D-Glucopyranoside 5a}

White solide. M.p. $166^{\circ} \mathrm{C}-167^{\circ} \mathrm{C} ;[\alpha]_{\mathrm{D}}^{20}=+103.1\left(\mathrm{c}=0.905, \mathrm{CHCl}_{3}\right) .{ }^{1} \mathrm{H}$ NMR $\left(400 \mathrm{MHz}, \mathrm{CDCl}_{3}\right) \delta$ 7.47-7.41 (m, 2H), $7.41-7.35$ (m, 3H), $5.61(\mathrm{~s}, 1 \mathrm{H}), 4.62(\mathrm{~d}, J=3.6 \mathrm{~Hz}, 1 \mathrm{H}), 4.18(\mathrm{dd}, J=9.9,4.8 \mathrm{~Hz}, 1 \mathrm{H}), 3.763 .56(\mathrm{~m}$, $3 \mathrm{H}), 3.48(\mathrm{t}, J=9.2 \mathrm{~Hz}, 1 \mathrm{H}), 3.29(\mathrm{~s}, 3 \mathrm{H}), 2.81$ (dd, $J=9.7,3.6 \mathrm{~Hz}, 1 \mathrm{H}) .{ }^{13} \mathrm{C}$ NMR $\left(100 \mathrm{MHz}, \mathrm{CDCl}_{3}\right) \delta 142.99$, 134.09, 133.24, 131.63, 106.13, 103.97, 87.27, 73.27, 72.63, 67.68, 59.96, 59.35. Anal. Calcd. (\%) for $\mathrm{C}_{14} \mathrm{H}_{19} \mathrm{NO}_{5}$ : C, 59.78; H, 6.81; N, 4.98; O, 28.44. Found: C, 59.764; H, 6.75; N, 4.81.

\subsection{Benzyl-4,6-0-Benzylidene-2-Amino-2-Deoxy- $\alpha$-D-Glucopyranoside $5 \mathrm{~b}$}

White solide. Mp $172.4^{\circ} \mathrm{C}-173.8^{\circ} \mathrm{C} .[\alpha]_{\mathrm{D}}^{20}=+59.7\left(\mathrm{c}=1.05, \mathrm{CHCl}_{3}\right) .{ }^{1} \mathrm{H}$ NMR $\left(400 \mathrm{MHz}, \mathrm{CDCl}_{3}\right) \delta 7.80-$ $6.91(\mathrm{~m}, 10 \mathrm{H}), 5.53(\mathrm{~s}, 1 \mathrm{H}), 4.90(\mathrm{~d}, J=3.6 \mathrm{~Hz}, 1 \mathrm{H}), 4.75(\mathrm{~d}, J=11.7 \mathrm{~Hz}, 1 \mathrm{H}), 4.52$ (d, $J=11.8 \mathrm{~Hz}, 1 \mathrm{H}), 4.24$ (dd, $J=10.1,4.8 \mathrm{~Hz}, 1 \mathrm{H}$ ), 3.88 (td, $J=9.9,4.8 \mathrm{~Hz}, 1 \mathrm{H}$ ), $3.83-3.66$ (m, $2 \mathrm{H}), 3.49$ (t, $J=9.3 \mathrm{~Hz}, 1 \mathrm{H}$ ), 2.81 (dd, $J=9.7,3.6 \mathrm{~Hz}, 1 \mathrm{H}) .{ }^{13} \mathrm{C}$ NMR $\left(100 \mathrm{MHz}, \mathrm{CDCl}_{3}\right) \delta 137.86,137.67,128.97,128.42,128.06,127.89,127.76$, 126.62, 101.47, 99.58, 82.08, 71.70, 69.33, 68.74, 63.30, 57.06. Anal. Calcd. (\%) for $\mathrm{C}_{20} \mathrm{H}_{23} \mathrm{NO}_{5}$ : C, 67.21; $\mathrm{H}$, 6.49; N, 3.92; O, 22.38. Found: C, 67.12; H, 6.32; N, 3.81.

\subsection{Methyl-4,6-0-Benzylidene-2-Acetylamino-2-Deoxy- $\alpha$-D-Glucopyranoside 4a}

White solide. M.p. $250^{\circ} \mathrm{C}-252^{\circ} \mathrm{C}$; $[\alpha]_{\mathrm{D}}^{20}=+90(\mathrm{c}=0.11, \mathrm{MeOH}) ;{ }^{1} \mathrm{H}$ NMR $(400 \mathrm{MHz}$, DMSO) $\delta 7.90(\mathrm{~d}, J=$ $8.4 \mathrm{~Hz}, 1 \mathrm{H}), 7.46$ (dd, $J=6.6,3.2 \mathrm{~Hz}, 2 \mathrm{H}), 7.41-7.35(\mathrm{~m}, 3 \mathrm{H}), 5.61(\mathrm{~s}, 1 \mathrm{H}), 4.62$ (d, $J=3.6 \mathrm{~Hz}, 1 \mathrm{H}), 4.18$ (dd, $J=9.9,4.8 \mathrm{~Hz}, 1 \mathrm{H}), 3.89-3.80(\mathrm{~m}, 1 \mathrm{H}), 3.74(\mathrm{t}, J=10.1 \mathrm{~Hz}, 1 \mathrm{H}), 3.69-3.63(\mathrm{~m}, 1 \mathrm{H}), 3.63-3.56(\mathrm{~m}, 1 \mathrm{H})$, $3.48(\mathrm{t}, J=9.2 \mathrm{~Hz}, 1 \mathrm{H}), 3.29$ (s, 3H), 1.85 (s, 3H). ${ }^{13} \mathrm{C}$ NMR (100 MHz, DMSO) $\delta 169.43,137.74,128.84$, 127.99, 126.37, 100.87, 98.71, 82.01, 68.02, 67.37, 62.43, 54.71, 54.10, 22.57. Anal. Calcd. (\%) for $\mathrm{C}_{16} \mathrm{H}_{21} \mathrm{NO}_{6}$ : C, 59.43; H, 6.55; N, 4.33; O, 29.69 Found: C, 59.67; H, 6.72; N, 4.21.

\subsection{Benzyl-4,6-0-Benzylidene-2-Acetylamino-2-Deoxy- $\alpha$-D-Glucopyranoside 4b}

White solide. M.p. $189^{\circ} \mathrm{C}-192^{\circ} \mathrm{C} ;[\alpha]_{\mathrm{D}}^{20}=+56(c=0.21, \mathrm{MeOH}) ;{ }^{1} \mathrm{H}$ NMR $(400 \mathrm{MHz}$, DMSO) $\delta 8.00(\mathrm{~d}, J=$ $8.2 \mathrm{~Hz}, 1 \mathrm{H}), 7.49-7.43$ (m, 2H), $7.42-7.33$ (m, 7H), 7.30 (ddd, $J=8.4,3.6,1.8 \mathrm{~Hz}, 1 \mathrm{H}), 5.62$ (s, 1H), 5.19 (d, $J=5.8 \mathrm{~Hz}, 1 \mathrm{H}), 4.80(\mathrm{~d}, J=3.6 \mathrm{~Hz}, 1 \mathrm{H}), 4.70(\mathrm{~d}, J=12.6 \mathrm{~Hz}, 1 \mathrm{H}), 4.49(\mathrm{~d}, J=12.6 \mathrm{~Hz}, 1 \mathrm{H}), 4.18-4.11(\mathrm{~m}$, 1H), 3.86 (ddd, $J=10.6,8.3,3.7 \mathrm{~Hz}, 1 \mathrm{H}$ ), 3.72 (ddd, $J=21.9,12.6,7.9 \mathrm{~Hz}, 3 \mathrm{H}$ ), 3.51 (t, $J=9.0 \mathrm{~Hz}, 1 \mathrm{H}$ ), 1.84 $(\mathrm{d}, J=9.8 \mathrm{~Hz}, 3 \mathrm{H}) .{ }^{13} \mathrm{C}$ NMR (100 MHz, DMSO) $\delta 169.93,138.19(\mathrm{~d}, J=3.3 \mathrm{~Hz}), 129.34,128.7,128.49$, 128.07 (d, $J=7.3 \mathrm{~Hz}$ ), 126.86, 101.34, 97.43, 69.06, 68.48, 67.73, 63.33 54.67, 23.00. Anal. Calcd. (\%) for $\mathrm{C}_{22} \mathrm{H}_{25} \mathrm{NO}_{6}$ : C, 66.15; H, 6.31; N, 3.51; O, 24.03. Found: C, 66.04; H, 6.15; N, 3.48.

\subsection{General Experimental Procedure for the Reduction of Imines with Trichlorosilane Catalyzed by 5 a}

To a stirred solution of imine 6 ( $0.5 \mathrm{mmol})$ and catalyst $\mathbf{5 a}(25 \mathrm{mg}, 0.05 \mathrm{mmol})$ in dry $\mathrm{CHCl}_{3}(2 \mathrm{~mL})$ was added 
the trichlorosilane $(0.1 \mathrm{ml}, 1 \mathrm{mmol})$ at $0^{\circ} \mathrm{C}$ and the reaction mixture was stirred at $0^{\circ} \mathrm{C}$ for $24 \mathrm{~h}$. Then, saturated $\mathrm{NaHCO}_{3}(2 \mathrm{ml})$ was added and extracted with $\mathrm{CHCl}_{3}(3 \times 5 \mathrm{ml})$. The combined organic phases were washed with saturated brine, dried over $\mathrm{MgSO}_{4}$, and concentrated in vacuo. Then the crude product was purified by column chromatography through silica gel, eluting with 1:99 ethyl acetate/petroleum ether solvent mixture, to give the pure 7 .

$\mathrm{N}$-Phenyl-1-phenylethylamine 7a Yield 91\%. Yellow oil. ${ }^{1} \mathrm{H}$ NMR (400 MHz, $\left.\mathrm{CDCl}_{3}\right) \delta 7.32-7.18(\mathrm{~m}, 4 \mathrm{H})$, $7.14(\mathrm{t}, J=7.1 \mathrm{~Hz}, 1 \mathrm{H}), 7.01(\mathrm{t}, J=7.6 \mathrm{~Hz}, 2 \mathrm{H}), 6.56(\mathrm{t}, J=7.2 \mathrm{~Hz}, 1 \mathrm{H}), 6.43(\mathrm{~d}, J=7.6 \mathrm{~Hz}, 2 \mathrm{H}), 4.41(\mathrm{q}, J=$ $6.6 \mathrm{~Hz}, 1 \mathrm{H}), 1.43(\mathrm{~d}, J=6.7 \mathrm{~Hz}, 3 \mathrm{H}) .{ }^{13} \mathrm{C}$ NMR $\left(1010 \mathrm{MHz}, \mathrm{CDCl}_{3}\right) \delta 146.26,144.20,128.07,127.60,125.83$, 124.82, 116.21, 112.29, 52.43, 23.98.

\section{Results and Discussion}

First we attempted to synthesize the carbohydrate-derived organocatalysts (Scheme 1). The amino group in the position C-2 of D-glucosamine hydrochloride $\mathbf{1}$ was first protected by acetylation. The hydroxyl group in the position C-1 was modified by glycoside and benzyl glycoside. Then the hydroxyl groups in the position C-4 and C-6 were protected by benzylidene acetal. Finally, the acetyl group in the position C-2 was removed by alkaline alcohol solution. The carbohydrate-derived alcohols $\mathbf{5}$ were obtained.

In order to screen the catalysts (Figure 1), the reduction of imine $\mathbf{5 a}$ with trichlorosilane was investigated as a model reaction. The results of the catalysts screening and condition optimizations are summarized in Table $\mathbf{1}$. In our initial practice, we attempted to use carbohydrate-derived amino alcohols $\mathbf{5 a}$ and $\mathbf{5 b}$ as catalysts at room temperature, affording 74\% yield and 63\% yield separately (Table 1, entries 1-2). Then, the carbohydrate-derived

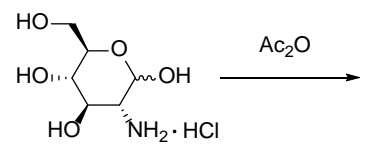

1

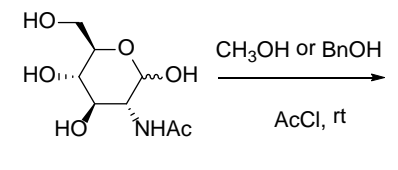

2

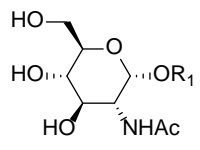

3a: $\mathrm{R}_{1}=\mathrm{CH}_{3}$
3b: $\mathrm{R}_{1}=\mathrm{Bn}$

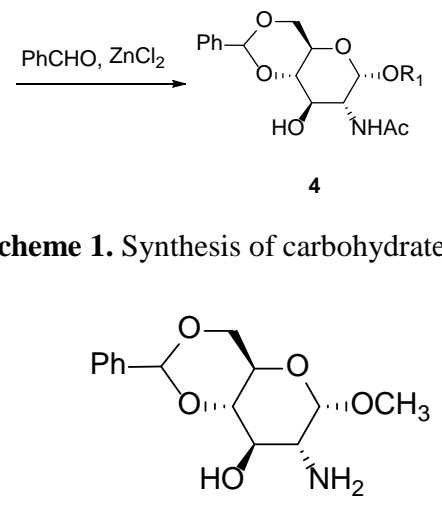

$5 \mathbf{a}$<smiles>CO[C@H]1C[C@H](O)[C@H]2OC(c3ccccc3)OC[C@H]2O1</smiles>

$4 a$<smiles>N[C@@H]1[C@H](O)[C@@H](Cc2ccccc2)O[C@@H]2COC(c3ccccc3)O[C@@H]21</smiles>

$5 b$<smiles>CC(=O)N[C@@H]1[C@H](O)[C@@H]2OC(c3ccccc3)OC[C@H]2O[C@H]1O</smiles>

$4 \mathrm{~b}$

Figure 1. Structures of carbohydrate-derived organocatalysts evaluated in this study. 
Table 1. Asymmetric reduction of imine $\mathbf{6} \mathbf{a}^{a}$.

\begin{tabular}{ccccc}
\hline Entry & Catalyst & Solvent & Temp $\left({ }^{\circ} \mathrm{C}\right)$ & ${\text { Yield }(\%)^{b}}^{b}$ \\
\hline 1 & $\mathbf{5 a}$ & $\mathrm{CH}_{2} \mathrm{Cl}_{2}$ & rt & 74 \\
2 & $\mathbf{b}$ & $\mathrm{CH}_{2} \mathrm{Cl}_{2}$ & rt & 63 \\
3 & $\mathbf{4 a}$ & $\mathrm{CH}_{2} \mathrm{Cl}_{2}$ & rt & 61 \\
4 & $\mathbf{4 b}$ & $\mathrm{CH}_{2} \mathrm{Cl}_{2}$ & rt & 34 \\
5 & $\mathbf{5 a}$ & $\mathrm{Toluene}$ & $\mathrm{rt}$ & 81 \\
6 & $\mathbf{5 a}$ & $\mathrm{CHCl}_{3}$ & $\mathrm{rt}$ & 54 \\
7 & $\mathbf{5 a}$ & $\mathrm{ClCH}_{2} \mathrm{CH}_{2} \mathrm{Cl}$ & $\mathrm{rt}$ & 69 \\
9 & $\mathbf{5 a}$ & $\mathrm{CHCl}_{3}$ & 0 & 91 \\
\hline
\end{tabular}

${ }^{a}$ The reactions were carried out with $10 \mathrm{~mol} \%$ catalyst and 2.0 equiv of $\mathrm{SiHCl}_{3}$ on a $0.5 \mathrm{mmol}$ scale in $2.0 \mathrm{~mL}$ of solvent for $24 \mathrm{~h}$. ${ }^{b}$ Isolated yield based on the imine.<smiles>C/C(=N/c1ccccc1)c1ccccc1</smiles>

$6 a$<smiles>CC(Nc1ccccc1)c1ccccc1</smiles>

$7 a$

acetamide alcohols $\mathbf{4 a}$ and $\mathbf{4 b}$ also could catalyze the reduction of imine $\mathbf{6 a}$ (Table 1, entries 3-4). The 67\% yield and $61 \%$ yield were obtained separately. Thus, the catalyst effect of carbohydrate-derived amino alcohols $5 \mathbf{a}$ was best. Then the optimization of reaction conditions was studied. The effect of solvent was firstly investigated (Table 1, entries 1, 5-7). We found that trichloromethane was the best solvent affording the product with 81\% yield (Table 1, entry 6). Therefor, the reaction temperature was further studied (Table 1, entries 1, 8-9). The best result was obtained at $40^{\circ} \mathrm{C}$, affording $91 \%$ yield (Table 1, entry 9). Thus, we selected $40^{\circ} \mathrm{C}$ as the best temperature in this reaction.

Encouraged by these results, the substrate scope of the reduction of imines with trichlorosilane was further studied under the optimized conditions. The results were summarized in Table 2. For aromatic $N$-Ph imines $\mathbf{6 b - 6 g}$ with electron-withdrawing groups, only 68-77\% yields were obtained (Table 2, entries 2-4). When aromatic $N$-Ph imines $\mathbf{6 c - 6 e}$ with electron-donating groups were reduced, the yields were increased to $94-95 \%$ (Table 2, entries 5-6). The benzyl $N$-Ph imine $\mathbf{6 h}$ could afford the $91 \%$ yield (Table 2, entry 7). Phenyl $N$-aryl imines 6i-6k with electron-withdrawing groups could be reduced in 78-82 yields (Table 2, entries 9-11). When the Phenyl $N$-aryl imine $\mathbf{6 l}$ with electron-donating group, the yield was also increased (Table 2, entry 12). $N$-aryl propiophenone imines were similar to $\mathrm{N}$-Ph acetophenone imines, affording the $78 \%$ - $89 \%$ yields (Table 2, entries 13-15).

\section{Conclusion}

In sum, we have described carbohydrate-derived organocatalyst for the reduction of imines with trichlorosilane. The backbone of D-glucosamine hydrochloride was fine-tuned and modified. The amino group in the position C-2 was first protected by acetylation. The hydroxyl group in the position C-1 was modified by glycoside and benzyl glycoside. Then the hydroxyl groups in the position C-4 and C- 6 were protected by benzylidene acetal. Finally, the acetyl group in the position C-2 was removed by alkaline alcohol solution. The carbohydrate-derived organocatalysts were screened. Methyl-4,6-O-benzylidene-2-amino-2-deoxy- $\alpha$-D-glucopyranoside was selected as the best catalyst. This reduction reaction of imines with trichlorosilane could be carried out in $\mathrm{CHCl}_{3}$ at $40^{\circ} \mathrm{C}$, affording $68 \%-94 \%$ yield. 
Table 2. Asymmetric reduction of imine 6 with catalyst $\mathbf{1}^{a}$.

\begin{tabular}{|c|c|c|c|c|c|}
\hline Entry & Imine & $\mathrm{R}_{1}$ & $\mathrm{R}_{2}$ & $\mathrm{R}_{3}$ & Yield (\%) ${ }^{b}$ \\
\hline 1 & $6 a$ & $\mathrm{C}_{6} \mathrm{H}_{5}$ & $\mathrm{C}_{6} \mathbf{H}_{5}$ & $\mathbf{C H}_{3}$ & 91 \\
\hline 2 & $6 b$ & $\mathbf{C}_{6} \mathbf{H}_{5}$ & $4-\mathrm{FC}_{6} \mathrm{H}_{4}$ & $\mathrm{CH}_{3}$ & 74 \\
\hline 3 & 6d & $\mathbf{C}_{6} \mathbf{H}_{5}$ & $4-\mathrm{ClC}_{6} \mathrm{H}_{4}$ & $\mathrm{CH}_{3}$ & 68 \\
\hline 4 & $6 f$ & $\mathbf{C}_{6} \mathbf{H}_{5}$ & $3-\mathrm{ClC}_{6} \mathrm{H}_{4}$ & $\mathrm{CH}_{3}$ & 76 \\
\hline 5 & $6 g$ & $\mathrm{C}_{6} \mathrm{H}_{5}$ & $3-\mathrm{BrC}_{6} \mathrm{H}_{4}$ & $\mathrm{CH}_{3}$ & 77 \\
\hline 6 & $6 c$ & $\mathrm{C}_{6} \mathrm{H}_{5}$ & $2-\mathrm{CH}_{3} \mathrm{C}_{6} \mathrm{H}_{4}$ & $\mathrm{CH}_{3}$ & 95 \\
\hline 7 & $6 e$ & $\mathrm{C}_{6} \mathrm{H}_{5}$ & $4-\mathrm{CH}_{3} \mathrm{C}_{6} \mathrm{H}_{4}$ & $\mathbf{C H}_{3}$ & 94 \\
\hline 8 & $6 h$ & $\mathrm{C}_{6} \mathrm{H}_{5}$ & $\mathrm{C}_{6} \mathrm{H}_{4} \mathrm{CH}_{2}$ & $\mathrm{CH}_{3}$ & 91 \\
\hline 9 & $6 \mathbf{i}$ & $4-\mathrm{FC}_{6} \mathrm{H}_{4}$ & $\mathrm{C}_{6} \mathrm{H}_{5}$ & $\mathrm{CH}_{3}$ & 81 \\
\hline 10 & $6 \mathbf{j}$ & $4-\mathrm{ClC}_{6} \mathrm{H}_{4}$ & $\mathbf{C}_{6} \mathbf{H}_{5}$ & $\mathrm{CH}_{3}$ & 78 \\
\hline 11 & $6 \mathbf{k}$ & $4-\mathrm{NO}_{2} \mathrm{C}_{6} \mathrm{H}_{4}$ & $\mathbf{C}_{6} \mathbf{H}_{5}$ & $\mathrm{CH}_{3}$ & 82 \\
\hline 12 & 61 & $4-\mathrm{CH}_{3} \mathrm{C}_{6} \mathrm{H}_{4}$ & $\mathbf{C}_{6} \mathbf{H}_{5}$ & $\mathrm{CH}_{3}$ & 94 \\
\hline 13 & $6 \mathrm{~m}$ & $\mathbf{C}_{6} \mathbf{H}_{5}$ & $\mathrm{C}_{6} \mathrm{H}_{5}$ & $\mathrm{CH}_{3} \mathrm{CH}_{2}$ & 87 \\
\hline 14 & $6 n$ & $4-\mathrm{ClC}_{6} \mathrm{H}_{4}$ & $\mathbf{C}_{6} \mathbf{H}_{5}$ & $\mathrm{CH}_{3} \mathrm{CH}_{2}$ & 78 \\
\hline 15 & 60 & $4-\mathrm{CH}_{3} \mathrm{C}_{6} \mathrm{H}_{4}$ & $\mathbf{C}_{6} \mathbf{H}_{5}$ & $\mathrm{CH}_{3} \mathrm{CH}_{2}$ & 89 \\
\hline
\end{tabular}

${ }^{a}$ The reactions were carried out with $10 \mathrm{~mol} \%$ catalyst and 2.0 equiv of $\mathrm{SiHCl}_{3}$ on a $0.5 \mathrm{mmol}$ scale in $2.0 \mathrm{~mL}$ of $\mathrm{CHCl}_{3}$ at $40{ }^{\circ} \mathrm{C}$ for $24 \mathrm{~h}$. ${ }^{b} \mathrm{Isolated}$ yield based on the imine.

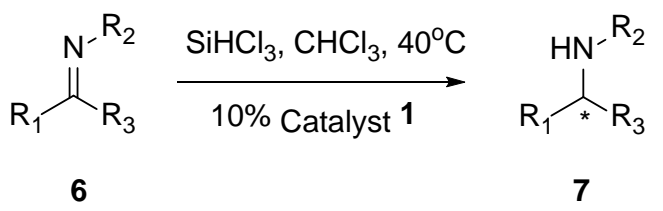

\section{Acknowledgements}

The authors thank for the financial support from the Natural Science Foundation of China (21376213) and the Research Fund for the Doctoral Program of Higher Education of China (20120101110062).

\section{References}

[1] Tripathi, R.P., Verma, S.S., Pandey, J. and Tiwari, V.K. (2008) Recent Development on Catalytic Reductive Amination and Applications. Current Organic Chemistry, 12, 1093-1115. http://dx.doi.org/10.2174/138527208785740283

[2] Crabtree, R. (1979) Iridium Compounds in Catalysis. Accounts of Chemical Research, 12, 331-338. http://dx.doi.org/10.1021/ar50141a005

[3] Connolly, T.J., Constantinescu, A., Lane, T.S., Matchett, M., Mcgarry, P. and Paperna, M. (2005) Assessment of a Reductive Amination Route to Methyl(3-nitrobenzyl)amine Hydrochloride. Organic Process Research \& Development, 9, 837-842. http://dx.doi.org/10.1021/op050120x

[4] Heydari, A., Khaksar, S., Akbari, J., Esfandyari, M., Pourayoubi, M. and Tajbakhsh, M. (2007) Direct Reductive Amination and Selective 1,2-Reduction of alpha,beta-Unsaturated Aldehydes and Ketones by $\mathrm{NaBH} 4$ Using $\mathrm{H}_{3} \mathrm{PW}_{12} \mathrm{O}_{40}$ as Catalyst. Tetrahedron Letters, 48, 1135-1138. http://dx.doi.org/10.1016/j.tetlet.2006.12.069

[5] Shen, C. and Zhang, P.F. (2013) D-Glucosamine-Derived Chiral Catalysts for Asymmetric Reactions. Current Organic Chemistry, 17, 1507-1524. http://dx.doi.org/10.2174/1385272811317140007

[6] Becker, C., Hoben, C. and Kunz, H. (2007) Enantioselective Organocatalysis of Strecker and Mannich Reactions Based on Carbohydrates. Advanced Synthesis \& Catalysis, 349, 417-424. http://dx.doi.org/10.1002/adsc.200600370 
[7] Liu, K., Cui, H.F., Nie, J., Dong, K.Y., Li, X.J. and Ma, J.A. (2007) Highly Enantioselective Michael Addition of Aromatic Ketones to Nitroolefins Promoted by Chiral Bifunctional Primary Amine-Thiourea Catalysts Based on Saccharides. Organic Letters, 9, 923-925. http://dx.doi.org/10.1021/ol0701666

[8] Dekamin, M.G., Azimoshan, M. and Ramezani, L. (2013) Chitosan: A Highly Efficient Renewable and Recoverable Bio-Polymer Catalyst for the Expeditious Synthesis of Alpha-Amino Nitriles and Imines under Mild Conditions. Green Chemistry, 15, 811-820. http://dx.doi.org/10.1039/c3gc36901c

[9] Shen, C., Shen, F.Y., Xia, H.J., Zhang, P.F. and Chen, X.Z. (2011) Carbohydrate-Derived Alcohols as Organocatalysts in Enantioselective Aldol Reactions of Isatins with Ketones. Tetrahedron: Asymmetry, 22, 708-712. http://dx.doi.org/10.1016/j.tetasy.2011.04.007

[10] Shen, C., Shen, F., Zhou, G., Xia, H., Chen, X., Liu, X. and Zhang, P. (2012) Novel Carbohydrate-Derived Prolinamide as a Highly Efficient, Recoverable Catalyst for Direct Aldol Reactions in Water. Catalysis Communications, 26, 6-10.

[11] Ji, L., Zhang, D.F., Zhao, Q., Hu, S.M., Qian, C. and Chen, X.Z. (2013) Diastereospecific Epoxidation and Highly Regioselective Ring-Opening of (+)-Valienamine: Practical Synthesis of (+)-Valiolamine. Tetrahedron, 69, 7031-7037. http://dx.doi.org/10.1016/j.tet.2013.06.046

[12] Xia, H.J., Yan, H., Shen, C., Shen, F.Y. and Zhang, P.F. (2011) Synthesis of Novel Carbohydrate-Based Chiral P, N Ligands and Their Applications in Cu-Catalyzed Enantioselective 1, 4-Conjugate Additions. Catalysis Communications, 16, 155-158. http://dx.doi.org/10.1016/j.catcom.2011.09.021

[13] Shen, C., Xia, H.J., Yan, H., Chen, X.Z., Ranjit, S., Xie, X.J., Tan, D., Lee, R., Yang, Y.M., Xing, B.G., Huang, K.W., Zhang, P.F. and Liu, X.G. (2012) A Concise, Efficient Synthesis of Sugar-Based Benzothiazoles through Chemoselective Intramolecular C-S Coupling. Chemical Science, 3, 2388-2393. http://dx.doi.org/10.1039/c2sc20248d

[14] Ge, X., Qian, C., Chen, Y.B. and Chen, X.Z. (2014) Novel Carbohydrate-Derived Pyridinecarboxylic Organocatalysts for the Enantioselective Reduction of Imines with Trichlorosilane. Tetrahedron: Asymmetry, 25, 596-601. http://dx.doi.org/10.1016/j.tetasy.2014.03.015

[15] Ji, L., Zhou, G.Q., Qian, C. and Chen, X.Z. (2014) Synthesis of 1,2,3-Triazoles from Azide-Derivatised Aminocyclitols by Catalytic Diazo Transfer and CuAAC Click Chemistry. European Journal of Organic Chemistry, 2014, 36223636. http://dx.doi.org/10.1002/ejoc.201301874

[16] Ge, X., Qian, C. and Chen, X.Z. (2014) Synthesis of Novel Carbohydrate-Based Valine-Derived Formamide Organocatalysts by CuAAC Click Chemistry and Their Application in Asymmetric Reduction of Imines with Trichlorosilane. Tetrahedron: Asymmetry, 25, 1450-1455. http://dx.doi.org/10.1016/j.tetasy.2014.10.003

[17] Emmerson, D.P.G., Hems, W.P. and Davis, B.G. (2006) Carbohydrate-Derived Amino-Alcohol Ligands for Asymmetric Alkynylation of Aldehydes. Organic Letters, 8, 207-210. http://dx.doi.org/10.1021/ol0525031

[18] Shen, C., Xia, H.J., Zheng, H., Zhang, P.F. and Chen, X.Z. (2010) Synthesis of Novel Carbohydrate-Based Iminophosphinite Ligands in Pd-Catalyzed Asymmetric Allylic Alkylations. Tetrahedron: Asymmetry, 21, 1936-1941. http://dx.doi.org/10.1016/j.tetasy.2010.06.037 